\title{
Pengaruh Penerapan Problem Based Learning (PBL) Terhadap Metakognisi Siswa
}

\author{
Ainun Hamimah' ${ }^{1)}$, Era Dewi Kartika ${ }^{2)}$ \\ ${ }^{1,2)}$ IKIP Budi Utomo Malang \\ Email: ainunhamimah911@gmail.com,erfolgera@gmail.com
}

\begin{abstract}
Metacognition is a arrangement of cognitive processes that strongly support student learning activities. The purpose of this study was to determine the effect of Problem Based Learning (PBL) learning models on metacognition of class XI students of MA Raudlatul Ulum II Putukrejo Gondanglegi. This research is a quasiexperimental study with the form of one group pre test-post test design. The sample of this research was 20 students of class XIA MA Raudlatul Ulum II Gondanglegi. Data collection techniques in this study use metacognition skills tests in the form of 25 statements that have been tested for validity and reliability. Testing the hypothesis in this study using paired sample t- test test analysis to test the difference in scores obtained by students from the pretest (initial test) and posttest (final test) data. The results showed that there was an effect of problem based learning learning model on metacognition students of class XI at MA Raudlatul Ulum II Gondanglegi. Paired sample t-test test results found t value of 9,130 with sig (2-tailed) 0,000 . Because the significance value (sig.) Is less than 0.05 (sig. $<0.05$ ), it can be concluded that $\mathrm{H}_{0}$ is rejected and $\mathrm{H}_{1}$ is accepted, meaning that there is an effect of problem based learning model on students' metacognition.
\end{abstract}

Keywords : problem based learning, metacognition.

\begin{abstract}
ABSTRAK
Metakognisi merupakan sebuah pengaturan proses kognitif yang sangat mendukung kegiatan belajar siswa. Tujuan dari penelitian ini untuk mengetahui pengaruh model pembelajaran Problem Based Learning (PBL) terhadap metakognisi siswa pada materi turunan fungsi kelas XI MA Raudlatul Ulum II Putukrejo Gondanglegi. Penelitian ini merupakan penelitian quasi experiment dengan bentuk one group pre test-post test design. Teknik pengumpulan data dalam penelitian ini menggunakan Inventori berupa Metacognitive Activities Inventory (MCA-I) yang dikembangkan oleh Cooper dan Sandi-urena (2009). Pengujian hipotesis pada penelitian ini menggunakan analisis Uji paired sampel t-test untuk pengujian perbedaan skor yang diperoleh siswa dari data pretest (tes awal) dan posttest (tes akhir). Hasil penelitian menunjukkan bahwa terdapat pengaruh model pembelajaran
\end{abstract}


problem based learning terhadap metakognisi siswa kelas XI di MA Raudlatul Ulum II Gondanglegi. Hasil uji paired sampel t-test ditemukan nilai t sebesar 9,130 dengan sig (2-tailed) 0,000. Oleh karena nilai signifkansi (sig.) kurang dari 0,05 (sig. < 0,05), maka dapat disimpulkan bahwa $\mathrm{H}_{0}$ ditolak dan $\mathrm{H}_{1}$ diterima, artinya ada pengaruh model pembelajaran problem based learning terhadap metakognisi siswa.

Kata Kunci : problem based learning, metakognisi.

\section{PENDAHULUAN}

Pendidikan merupakan salah satu hal yang sangat penting dalam kehidupan, yaitu suatu usaha manusia agar dapat mengembangkan potensi dirinya melalui proses pembelajaran sehingga dapat menciptakan kehidupan yang lebih baik. Oleh karena itu, matematika merupakan salah satu bidang studi yang menduduki peranan penting dalam pendidikan tersebut. Karakteristik dari matematika salah satunya adalah memiliki objek kajian yang bersifat abstrak, untuk dapat memahami matematika bukan hal yang mudah. Oleh karena itu, dibutuhkan upaya siswa untuk mempelajari dan memahami matematika secara intensif sehingga pencapaian hasil belajar bisa optimal. Upaya belajar yang dibutuhkan siswa dalam mempelajari dan memahami matematika itu adalah dengan belajar berdasarkan metakognisinya (Sumardyono, 2004: 31). Sili (2018) juga mengatakan bahwa proses metakognisi siswa dalam pemecahan masalah matematika perlu diketahui. Huitt dalam Sudia (2015: 30) mendefinisikan "Metakognisi sebagai pengetahuan seseorang tentang kognitifnya, berpikir seseorang tentang berpikirnya, dan keterampilan esensial seseorang dalam belajar untuk belajar". Brown dalam Mustamin Anggo (2012: 22) menggambarkan bahwa "Metakognisi terdiri dari aktivitas untuk mengatur dan memantau belajar manusia”.

Berdasarkan hasil observasi yang dilakukan peneliti pada siswa kelas XI MA Raudlatul Ulum Putukrejo Gondanglegi, diketahui bahwa mata pelajaran matematika masih tergolong rendah salah satunya pada materi Turunan Fungsi, hal ini terlihat pada rata - rata nilai raport semester ganjil adalah $47-59$. Hal lain yang terjadi pada kelas XI MA Raudlatul Ulum Gondanglegi adalah aktivitas-aktifitas kognitif siswa kelas XI dalam kegiatan pembelajaran matematika belum optimal. Model pembelajaran yang dirasa mampu mewujudkan situasi pembelajaran yang diharapkan adalah Problem Based Learning (PBL). Beberapa penelitian telah menunjukkan hasil bahwa strategistrategi pembelajaran tertentu dapat memberdayakan keterampilan berpikir maupun 
keterampilan metakognisi. Hadi (2009) menyatakan bahwa PBL dapat meningkatkan keterampilan metakognisi dan pemahaman konsep siswa pada kemampuan akademik berbeda.

Problem Based Learning (PBL) merupakan model pembelajaran kooperatif dimana dengan model pembelajaran ini menantang siswa untuk "belajar bagaimana belajar" bekerja bersama kelompok untuk mencari solusi dari permasalahan nyata siswa. Zamzam (2016) mengatakan bahwa PBL dapat membuat siswa lebih aktif selama proses pembelajaran. Melalui pembelajaran PBL ini diharapkan metakognisi siswa dapat terkontrol dan meningkat. Metakognisi yang dimaksudkan pada penelitian ini adalah keterampilan metakognisi. Keterampilan metakognisi diukur menggunakan Metacognitif Activities Inventory (MCA-I) menurut teori Cooper dan Sandi-Urena (2009) dengan tiga aspek, yaitu: aspek perencanaan, pemantauan dan evaluasi

\section{METODE PENELITIAN}

Penelitian ini menggunakan rancangan penelitian yaitu quasi experiment (eksperimen semu), dengan bentuk one group pretest posttest design. Populasi dalam penelitian ini adalah seluruh siswa kelas XI MA Raudlatul Ulum Putukrejo tahun ajaran 2017-2018. Penentuan sampel dengan teknik purposive sampling dan diperoleh jumlah sampel sebanyak 20 siswa dari 44 siswa.

Data yang dikumpulkan meliputi data tes keterampilan metakognisi siswa. Nilai keterampilan metakognisi diperoleh dari pretest dan posttest yang kemudian ditentukan nilai presentase dari setiap butir pernyataan tes keterampilan metakognisi. Data yang diperoleh dari tes keterampilan metakognisi dianalisis dengan Uji paired sample t-test atau uji-t sampel berpasangan pada taraf signifikansi 5\%. Sebelum dilakukan uji hipotesis, terlebih dahulu dilakukan uji normalitas sebaran data menggunakan statistik Kolmogorov-Smirnov,dengan bantuanprogram SPSS 17.0 for Windows.

\section{HASIL DAN PEMBAHASAN}

\section{Hasil}

Penelitian ini dilakukan di kelas XI MA Raudlatul Ulum Putukrejo yang mempunyai sampel sebanyak 20 siswa. Kelas eksperimen diberi perlakuan dengan 
menggunakan model pembelajaran problem based learning. Data yang diperoleh dari penelitian ini adalah data kuantitatif. Data kuantitatif berupa tes keterampilan metakognisi siswa yang diperoleh dari hasil pretes dan postes yang dilakukan di kelas eksperimen tersebut. Tes keterampilan metakognisi siswa berupa 25 pernyataan yang telah diuji validitasnya dikelas X, XIB dan XII MA Raudlatul Ulum II Putukrejo. Dalam uji validitas ini menggunakan rumus korelasi Pearson Product Moment dengan menggunakan Program SPSS versi 17.0. Nilai tabel dalam uji validitas ini untuk 60 responden dengan taraf siignifikansi $5 \%$ adalah 0,244. Oleh karena itu, dapat disimpulkan bahwa instrumen keterampilan metakognitif yang berjumlah 25 pernyataan dinyatakan valid, karena semua item pernyataan berada pada I' ${ }_{\text {hitung }}>I^{\prime}$ tabel, sehingga instrumen ini layak digunakan dalam penelitian ini. Kemudian hasil penelitian yang diperoleh akan di uji secara statistik untuk mengetahui pengaruh perlakuan yang sudah diberikan terhadap metakognisi siswa.

Nilai pretest kelas eksperimen dilihat dari persentase setiap aspek keterampilan metakognisi lebih rendah dibandingkan dengan nilai posttest yakni pada aspek perencanaan $67 \%<74 \%$, aspek pemantauan $65 \%<73 \%$ dan aspek evaluasi $66 \%<71 \%$. Nilai pretest kelas eksperimen dilihat dari nilai maksimal, nilai minimal dan nilai rata-rata lebih rendah dibandingkan dengan nilai posttest yakni berturut-turut $75<84,58<65$ dan $66<73,5$. Hasil pengujian normalitas menggunakan uji Kolmogorov-Smirnovdiperoleh angka (sig.) > 0,05 yaitu 0,200 dan 0,200. Hasil ini menunjukkan bahwa data tes keterampilan metakognisi merupakan data yang terdistribusi normal. Setelah data dinyatakan terdistribusi normal, maka langkah berikutnya adalah pengujian hipotesis menggunakan Uji Paired Sample t-test pada taraf signifikansi 5\%. Berdasarkan hasil Uji Paired Sample t-test di atas, diperoleh nilai (sig.) lebih kecil dari 0,05 (sig. <0,05) yaitu 0,000. Dapat disimpulkan bahwa $\mathrm{H}_{0}$ ditolak dan $\mathrm{H}_{1}$ diterima, artinya terdapat pengaruh model pembelajaran problem based learning terhadap keterampilan metakognisi siswa.

\section{Pembahasan}

Berdasarkan hasil perhitungan pretes dan posttest, menunjukkan bahwa terdapat perbedaan rata-rata keterampilan metakognisi, nilai rata-rata postest keterampilan metakognisi siswa lebih tinggi dibandingkan nilai rata-rata pretest keterampilan metakognisi siswa. Adanya perbedaan rata-rata keterampilan 
metakognisi siswa pada hasil pretest dan postest dipengaruhi oleh penggunaan pembelajaran model PBL. Pembelajaran model PBL mendukung penggunaan metakognisi siswa dalam menghadapi masalah.

Jika ditinjau dari sebagaimana hasil deskripsi data, keterampilan metakognisi meliputi tiga aspek, yakni aspek perencanaan, aspek pemantauan dan aspek evaluasi. Indikator pertama pada aspek perencanaan yaitu terhubung dengan pengetahuan terdahulu, indikator ini memperoleh presentase sebesar $65,5 \%$ (pretest) dan $71,5 \%$ (posttest). Indikator kedua pada aspek perencanaan adalah mengidentifikasikan tujuan, presentase ketercapaian indikator ini mencapai $73 \%$ (pretest) dan $79 \%$ (posttest). Persentase tertinggi pada aspek keterampilan perencanaan adalah indikator memilah informasi penting yaitu mencapai $75 \%$ (pretest) dan $81 \%$ (posttest). Indikator dalam keterampilan perencanaan yang mencerminkan proses siswa dalam memahami masalah dalam penelitian ini yaitu memecahkan masalah menjadi poin-poin sebesar $61 \%$ (pretest) dan $66 \%$ (postest), menemukan hubungan dari setiap variabel sebesar $64 \%$ (pretest) dan $74 \%$ (postest). Kedua indikator tersebut saling menunjukkan adanya peningkatan yang baik. Indikator pada keterampilan perencanaan yang lain yaitu membuat penyelidikan memperoleh persentase sebesar $64 \%$ (pretest) dan $74 \%$ (posttest). Persentase ini menggambarkan bahwa keterampilan perencanaan siswa menjadi lebih baik dengan model PBL. Aspek keterampilan perencanaan dalam penelitian ini berkembang dengan baik pada kelompok eksperimen dengan penerapan model PBL, yaitu dengan perolehan persentase sebesar $67 \%$ (pretest) dan $74 \%$ (posttest).

Indikator memeriksa berbagai tahapan merupakan salah satu indikator keterampilan metakognisi dalam aspek pemantauan. Indikator ini memperoleh persentase sebesar $67 \%$ (pretest) dan 72\% (posttest). Mengidentifikasikan kesalahan, menilai jawaban, serta mengoreksi cara yang salah atau kurang tepat juga merupakan indikator dalam keterampilan pemantauan. Masing- masing indikator ini memperoleh persentase sebesar $71 \%, 74 \%$, dan $68 \%$. Indikator pemantauan yang lain adalah bertanya kepada teman, indikator ini mengalami kenaikan persentase yaitu sebesar 66\% (pretest) menjadi 77,5\% (posttest). Aspek keterampilan pemantauan memperoleh persentase sebesar $73 \%$, persentase ini dikategorikan baik. 
Indikator mengecek kembali jawaban akhir merupakan indikator pertama dalam keterampilan evaluasi yang menunjukan persentase sebesar 65\% (pretest) dan $71 \%$ (posttest). Indikator memverifikasi jawaban apakah menjawab pertanyaan, meningkat dari $67 \%$ (pretest) menjadi $70 \%$ (posttest). Keterampilan evaluasi dalam penelitian ini memperoleh persentase sebesar 71\%. Hal ini menunjukan bahwa keterampilan metakognisi siswa dengan diterapkan menggunakan model PBL menjadi lebih baik dibandingkan sebelum diberi perlakuan.

Demikian dapat dikatakan bahwa penggunaan model pembelajaran Problem Based Learning (PBL) memiliki pengaruh yang signifikan terhadap keterampilan metakognisi siswa pada materi Turunan Fungsi. Hasil penelitian ini sejalan dengan hasil penelitian Tosun dan Erdal (2013) yang dalam penelitiannya menyimpulkan bahwa model pembelajaran PBL memberikan pengaruh yang signifikan pada ketiga aspek keterampilan metakognisi tersebut.

\section{KESIMPULAN DAN SARAN}

\section{Kesimpulan}

Berdasarkan hasil penelitian dan analisa data serta pembahasan yang telah diuraikan pada bab sebelumnya, maka dapat disimpulkan bahwa:

1. Terdapat perbedaan keterampilan metakognisi siswa kelas XIA MA Raudlatul Ulum II, sebelum dan sesudah diberi perlakuan menggunakan model pembelajaran Problem Based Learning (PBL). Hal ini dapat dibuktikan dari rata-rata persentase postest siswa lebih baik setelah diberikan treatment menggunakan model pembelajaran problem based learning (PBL).

2. Model pembelajaran Problem Based Learning (PBL) memberikan pengaruh yang signifikan terhadap keterampilanmetakognisi siswa. Pengaruh tersebut ditunjukkan oleh hasil uji analisis paired T Test yakni nilai (sig.) lebih kecil dari 0,05 (sig. $<0,05$ ) yaitu 0,000 . Sehingga $\mathrm{H}_{0}$ ditolak dan $\mathrm{H}_{1}$ diterima, yang artinya terdapat pengaruh penerapan pembelajaran Problem Based Learning (PBL) terhadap metakognisi siswa kelas XI MA Rudlatul Ulum II Putukrejo pada materi Turunan Suatu Fungsi. 
Saran

Berdasarkan hasil penelitian yang telah dilakukan, maka saran yang dapat diberikan dari peneliti adalah sebagai berikut :

1. Model pembelajaran Problem Based Learning (PBL) sangat membantu guru dalam menghadirkan model pembelajaran yang dapat memfasilitasi siswa dalam proses pemecahan masalah nyata matematika siswa.

2. Dalam pelaksanaan model pembelajaran Problem Based Learning (PBL), guru harus menguasai dengan baik situasi pembelajaran agar aktivitas siswa dapat berjalan dengan baik sesuai dengan instruksi yang diberikan.

3. Bagi peneliti selanjutnya yang menggunakan model pembelajaran $P B L$ hendaknya dapat menambah variabel yang diukur sehingga keterampilan metakognisi siswa benar-benar dapat dikembangkan lebih tinggi lagi.

\section{REFERENSI}

Anggo, Mustamin. 2012. Metakognisi dan Usaha Mengatasi Kesulitan dalam Memecahkan Masalah Matematika Kontekstual. Aksioma. Vol 01, No 1.

Cooper, M. M., dan Sandi-Urena, S. (2009). Design and Validation of an Instrument To Asses Metacognitive Skillfulness in Chemistry Problem Solving. Journal of Chemical Education, 86(2).

Hadi, A. N. 2009. Pengaruh Penerapan Strategi Pembelajaran Problem Based Learning (PBL) terhadap keterampilan Metakognitif dan Pemahaman Konsep Siswa Kelas X di SMA Negeri 8 Malang pada Kemampuan Akademik Berbeda. Skripsi tidak diterbitkan, Malang:FMIPA UM.

Sili, Isabela F.K. dan Dian F.A. 2018. Analisis Proses Metakognisi dalam Pemecahan Masalah Matematika Ditinjau dari Gaya Kognitif. Jurnal Prismatika, Volume 1, Nomor 1.

Sudia, Muhammad. 2015. Profil Metakognisi Siswa SMP Dalam Memecahkan Masalah Open-Ended Ditinjau Dari Tingkat Kemampuan Siswa. Vol 01, No 01 .

Sumardyono. 2004. Karakteristik Matematika dan Implikasinya terhadap Pembelajaran Matematika. Yogyakarta: Depdiknas.

Zamzam, Kenys Fadhilah. 2016. Pendekatan Problem Based Learning untuk Mengembangkan Kemampuan Berpikir Kritis Mahasiswa. Jurnal Pedagogia, Volume 5, Nomor 2. 